\title{
Stable water isotope signatures of dual monsoon precipitation: A case study of Greater Cochin region, south-west coast of India
}

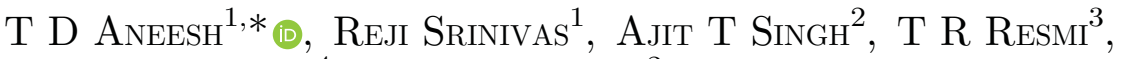 \\ ArChana M NAIR ${ }^{4}$ and B L RedKAR ${ }^{2}$ \\ ${ }^{1}$ National Centre for Earth Science Studies, Akkulam, Thiruvananthapuram, Kerala 695 011, India. \\ ${ }^{2}$ National Centre for Antarctic and Ocean Research, Headland Sada, Vasco-da-Gama, Goa 403 804, India. \\ ${ }^{3}$ Center for Water Resource Management and Development, Calicut, Kerala 695 121, India. \\ ${ }^{4}$ Indian Institute of Technology Guwahati, Amingaon, North Guwahati, Assam 781 039, India. \\ ${ }^{*}$ Corresponding author. e-mail: tdaneesh@gmail.com
}

MS received 13 December 2018; revised 9 March 2019; accepted 28 May 2019

Precipitation samples of various spatio-temporal scales were collected from coastal, midland and urban regions of Greater Cochin, Ernakulam district, Kerala for a period of 1 yr (2015-2016). The collected samples were analysed for stable water isotopes (SWI) $\left(\delta \mathrm{D}\right.$ and $\left.\delta^{18} \mathrm{O}\right)$, to understand these variations in the precipitation source and the factors governing its isotopic characteristics during precipitation. The $\delta^{18} \mathrm{O}$ in rainwater varies from $-8.73 \%$ to $0.29 \%$ in urban, $-12.21 \%$ o to $2.59 \%$ in midland and $-9.99 \%$ to $0.97 \%$ o in lowland regions. Spatio-temporal variations in SWI were observed in various regions, suggesting altitude and continental effect followed by the establishment of a regional overall local meteoric water line (LMWL) $\delta \mathrm{D}=8.06( \pm 0.15)$ $\delta^{18} \mathrm{O}+12.5( \pm 0.68)$. Among the coastal, midland and urban regions, the highest slope $(\sim 8.3)$ and intercept $(\sim 13.0)$ were observed in the urban region, which designates the variations in temperature along spatial and different layers of the atmosphere in the urban region, resulting in the deviation of isotopic characteristics. The overall deuterium excess ( $d$-excess) value is $\sim 10 \%$ during the south-west monsoon (June-September), suggesting a moisture source of marine origin. A $d$-excess of $\sim 13 \%$ is observed during the north-east monsoon, indicating a moisture source from the continental contribution (October-December). The results of the moisture source obtained from the $d$-excess value are also supported by back-trajectory analysis. Thus, the present study on isotopic characterisation of precipitation and its controlling factor may enhance our understanding of the Indian monsoon and its dynamics in the west coast region of India.

Keywords. Stable water isotopes; LMWL; d-excess; back-trajectory; monsoon; Greater Cochin.

\section{Introduction}

Monsoon in the Indian sub-continent originates from the southern Indian Ocean and the Arabian Sea (AS). Consequently, the Indian summer monsoon hit first along the western coast of Kerala state considerably influencing the weather pattern across India. The economy of the country is highly dependent on the agricultural sector which in turn is influenced by climate and availability of water

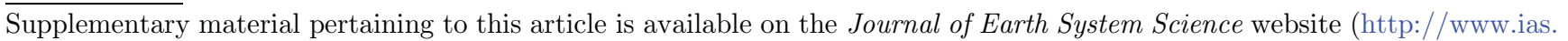
ac.in/Journals/Journal_of_Earth_System_Science).

Published online: 27 July 2019 
for irrigation (Saranya et al. 2018). Since the primary source of water on land is through precipitation, its spatial and temporal variation has considerable significance in the hydrologic cycle. Therefore, atmospheric water vapour causing the formation of clouds, is a significant component in the hydrological cycle for which more attention is required from researchers in elucidating the meteorological process in the atmosphere (Oltmans and Hoffmann 1995; Houghton et al. 2001; Hoffmann et al. 2005; Deshpande et al. 2010; Unnikrishnan Warrior et al. 2010). The regional scale variation in meteorological parameters are mainly influenced by topography and moisture source (Roderick and Farquhar 2002; Trenberth 2002). Thus, the effect of the regional climate and distribution pattern of moisture on continental areas is being studied to understand the different aspects in meterology. Spatial distribution of stable water isotopes (SWI) of oxygen and hydrogen from meteoric water has been used as powerful tracers by various researchers in identifying the hydrological processes. Spatial variation in the isotopic composition of water depends upon isotopic fractionation occurring during evaporation, transportation, condensation, precipitation and re-evaporation during the downfall from the cloud level to the ground level (Dansgaard 1964). Additionally, the transport history of air mass trajectories over continents and its rainout pattern also has control over the isotope composition during local precipitation (Rozanski et al. 1982). These concepts summarise that studies on rainwater isotopes can tell us details regarding the dynamic processes involved during the evolution, formation and downfall of rain water.

It is well established that the stable isotope composition of water $\left(\delta \mathrm{D}\right.$ and $\left.\delta^{18} \mathrm{O}\right)$ is useful to investigate various components of the hydrological cycle, such as precipitation, groundwater recharge, effect of evaporation, groundwater and surface water interaction (Gonfiantini 1986; Rozanski et al. 1993; Mathieu and Bariac 1996; Clark and Fritz 1997). Spatial and temporal studies on regional precipitation provide limited information about local moisture characteristics, especially in regions where evapotranspiration plays a significant role (Laskar et al. 2010). Thus, a detailed evaluation of isotopic fractionation during air parcel transport is necessary to understand the exact process which alters the source signature (Chakraborty et al. 2016). The relationship between $\delta \mathrm{D}$ and $\delta^{18} \mathrm{O}$ in fresh surface waters from different locations around the globe is defined by the equation $\delta \mathrm{D}=8 \delta^{18} \mathrm{O}+$ $0 \%$ SMOW (standard mean ocean water; Craig 1961), which is known as the global meteoric water line (GMWL). Rozanski et al. (1993) redefined this equation to long-term arithmetic means: $\delta \mathrm{D}=$ $(8.17 \pm 0.06) \quad \delta^{18} \mathrm{O}+(10.35 \pm 0.65) \%$ VSMOW (Vienna standard mean ocean water) and longterm weighted means: $\delta \mathrm{DW}=(8.20 \pm 0.07)$ $\delta^{18} \mathrm{O}+(11.27 \pm 0.65) \%$ VSMOW by weighing the amount of precipitation only. This is in consideration with the average of many local meteoric water lines (LMWLs), which is based on the variations in meteorological and geographical parameters. These correlations suggest a variation of the $\delta \mathrm{D}$ and $\delta^{18} \mathrm{O}$ relationship from region to region, which allows the establishment of the LMWL of a region specifically (Simpkins 1995; Gupta and Deshpande 2003, 2005; Gammons et al. 2006; Rhodes et al. 2006; Wassenaar et al. 2011; Hu et al. 2013; Hunjak et al. 2013; Stumpp et al. 2014). Thus, the variations of LMWL with respect to GMWL can significantly help to determine the source of precipitation reflecting the influence of non-equilibrium fractionation, which is defined as deuterium excess (d-excess) (Dansgaard 1964), which is the intercept of the meteoric water line. $d$-excess of precipitation provides information regarding meteorological conditions at the vapour source region. Another phenomenon that changes the isotopic composition of rainfall is cyclone and depression associated with intense isotope fractionation during its formation and movement across its track (Gedzelman et al. 2003; Tremoy et al. 2012; Good et al. 2014; Lekshmy et al. 2015; Rahul et al. 2016). For a mean relative humidity of $85 \%$ over the ocean, deuterium excess corresponds to a value of $10 \%$ during summer, whereas in winter it lowers to about $10 \%$. It is also noted that the inverse relationship between the deuterium excess value and relative humidity of the vapour source region showing a lowering of $d$-excess value in residential water bodies and a rise of $d$-excess value in evaporating water. Thus, precipitation samples formed by the condensation of such vapour are usually characterised by a high $d$-excess value.

Kerala is one of the biodiversity hotspots and contributes significantly to the agricultural sector of the country; studies on precipitation dynamics in this region are very much required. Kerala is under the influence of the south-west monsoon (SWM) during June, July, August, September (JJAS) and the north-east monsoon (NEM) starts by October and extends up to January (ONDJ). 
Only few SWI studies on precipitation samples have been carried out in Kerala (Soman et al. 1988; Unnikrishnan Warrier and Babu 2011; Lekshmy et al. 2014; Resmi et al. 2016; Unnikrishnan Warrier et al. 2015). The present study area of Greater Cochin is located in the central part of Kerala, which is classed as a Tier-II metro in India. In the study, we aim to understand the spatial and temporal variation of SWI and related factors governing its spatial changes in the urban city and its outskirts. These parameters are studied by analysing rainwater samples collected on a monthly resolution from five locations in three physiographical regions in Ernakulam district of Kerala state during the period of September 2015September 2016.

\section{Study area}

Geographically, Kerala state is located along the south-western corner of the Indian subcontinent covering an area of $\sim 38,800 \mathrm{~km}^{2}$ and extending between $8.2-12.8^{\circ} \mathrm{N}$ and $74.8-77.5^{\circ} \mathrm{E}$. The geographic location of Kerala is peculiar in such a way that it is situated across the path of the maritime air blow from the Indian Ocean and AS (Unnikrishnan Warrier and Babu 2011). During the northern hemispheric summer, moist air undergoes an orographic uplift along the windward slopes of the north-south oriented Western Ghats mountain series which runs parallel to the Indian peninsula and gives rise to copious rains in Kerala forming the SWM. In the Indian continent, SWM first outbursts are over the Kerala region, which start from the first week of June and extend up to September (Menon and Rajan 1989). Major sources of moisture for SWM in the southern Indian peninsula are from the northern part of the Indian Ocean and AS (Ghosh et al. 1978). The source of moisture for the NEM is from the southern part of the Indian Ocean, the Bay of Bengal (BoB) and continental vapour, which provides precipitation along the eastern and the south-eastern part of the peninsula (Menon and Rajan 1989). The isotopic signatures from these monsoon regimes are expected to show distinctive compositions, depending on its moisture sources and other local effects.

The present study is conducted in Greater Cochin region, a fast growing Tier-II metro located in Ernakulam district of Kerala, India (figure 1). The region covers an area of $\sim 900 \mathrm{~km}^{2}$ and lies between $9^{\circ} 48^{\prime} \mathrm{N}$ and $10^{\circ} 16^{\prime} \mathrm{N}$ latitude and $76^{\circ} 16^{\prime} \mathrm{E}$ and $76^{\circ} 25^{\prime} \mathrm{E}$ longitude (Aneesh et al. 2018). The study region is sub-divided geographically into lowland and midland area. The lowland area includes the coastal area, which is a 'plain' land with low relief and slope, having an elevation up to $5 \mathrm{~m}$ above mean sea level and width of about $10-15 \mathrm{~km}$ with a total area of $112 \mathrm{~km}^{2}$. The coastal plain is dominated by large numbers of backwater channels, covered with coastal alluvial soil of recent ages. The urban region starts from the coastal region itself and extends up to the midland region, with an elevation varying between 5 and $20 \mathrm{~m}$, with a total area coverage of $350 \mathrm{~km}^{2}$. The natural setting of the area is converted perfectly into metro status with perceptible land-use changes. In the study region, the urban area is underlined by unconsolidated alluvium followed by laterites of tertiary age. The midland region rises gently from the coastal plain in the west to east, with an elevation varying between 7 and $75 \mathrm{~m}$ with an aerial extent of $452 \mathrm{~km}^{2}$. The area is mostly covered by laterite on the west and crystalline rock exposures in the east.

Hydrologically, the study region lies between the Periyar river and its tributaries on the north and the Muvattupuzha river on the south. The upstream areas of the Periyar and Muvattupuzha river basin drainage patterns are trellis to subtrellis. The main channel of the Periyar is the longest river in Kerala state, which originates from the cardamom hills of the Western Ghats. Groundwater is under phreatic conditions in recent alluvium and under semi-confined to confined conditions in the underlying tertiary unconsolidated laterites (CGWB 2001).

Climatologically, the study area is humid, which experiences the summer season from March to May, SWM from June to September and, NEM during October to December and winter season in January and February (CGWB 2001). The average annual rainfall received in the study region is $\sim 298 \mathrm{~cm}$, with a total of 132 rainy days, out of which $\sim 67 \%$ is from the SWM during June to September and $\sim 18 \%$ from the NEM during October to December (postmonsoon) while remaining $15 \%$ precipitation happens during January to May (pre-monsoon). The Indian summer monsoon falls over most part of the continent during June-September caused by seasonal reverse wind, which brings moisture from AS and BoB. During the winter season, air blows from land, resulting in a dry winter monsoon (Sanyal and Sinha 2010). The study region experiences heavy rainfall on its eastern part compared to the west. The maximum 


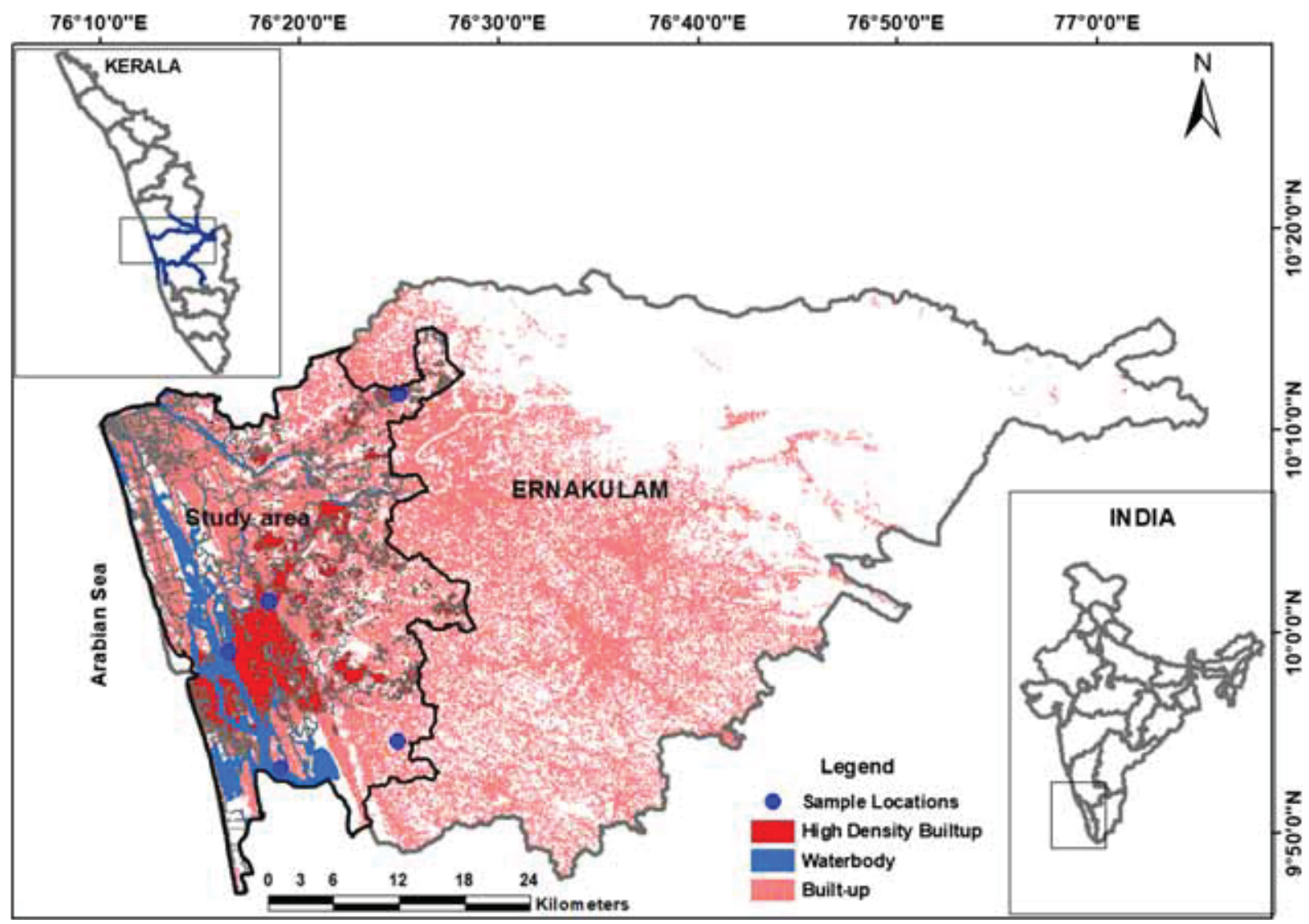

Figure 1. Study area.

temperature varies from $28.1^{\circ} \mathrm{C}$ to $31.4^{\circ} \mathrm{C}$ and minimum temperature, from $23.2^{\circ} \mathrm{C}$ to $26^{\circ} \mathrm{C}$. Humidity of the region varies from $68 \%$ to $89 \%$ during morning and $64 \%$ to $87 \%$ during evening hours. The relative humidity is found to be higher from May to October. The potential evapo-transpiration varies from 94.5 to $159.2 \mathrm{~mm}$ per month and $1424.1 \mathrm{~mm}$ per yr as per Penmann's method, which is observed during 1931-1960 from the Cochin observatory by the India Meteorological Department (IMD) and is adapted from CGWB (2003). The wind direction during morning hours is from the east and the north-east and changes to the west and the northwest during evening hours. The wind speed ranges between 6.7 and $10.9 \mathrm{~km} / \mathrm{h}$ with a mean speed of 9.1 $\mathrm{km} / \mathrm{h}$. High wind speed is observed during March-September (CGWB 2003).

\section{Materials and methods}

Rainwater samples are collected for SWI studies between September 2015 and September 2016, from the representative rain gauge station by following the norms of the International Atomic Energy Agency (IAEA). Rain water samples are collected from selected places, viz., for the urban region from Edapalli (ERR-I), for coastal region sampling from Cochin (ERR-IV) and Aroor (ERR$\mathrm{V})$. Additionally, two representative samples were collected from the midland region, one from Angamali (ERR-II) and Mulanthuruthi (ERR-III) (figure 2). Precipitation samples were collected using a large funnel with a diameter of $21 \mathrm{~cm}$, by fixing it on the carboy. Two thick plastic tubes are connected to the carboy out of which one is connected to the stem of the funnel extending up to the bottom of the carboy where the other facilitates the overflow of excess rain water. The monthly composite precipitation samples are sub-sampled using high-density polyethylene bottles with $60 \mathrm{ml}$ capacity. Meteorological data sets like temperature, humidity and rainfall are collected from the portal of the India Meteorological Department (IMD 2016).

All samples are analysed for $\delta^{18} \mathrm{O}$ and $\delta \mathrm{D}$ isotopes at the National Centre for Antarctic and Ocean Research, Ice Core Division, using OA-ICOS laser 


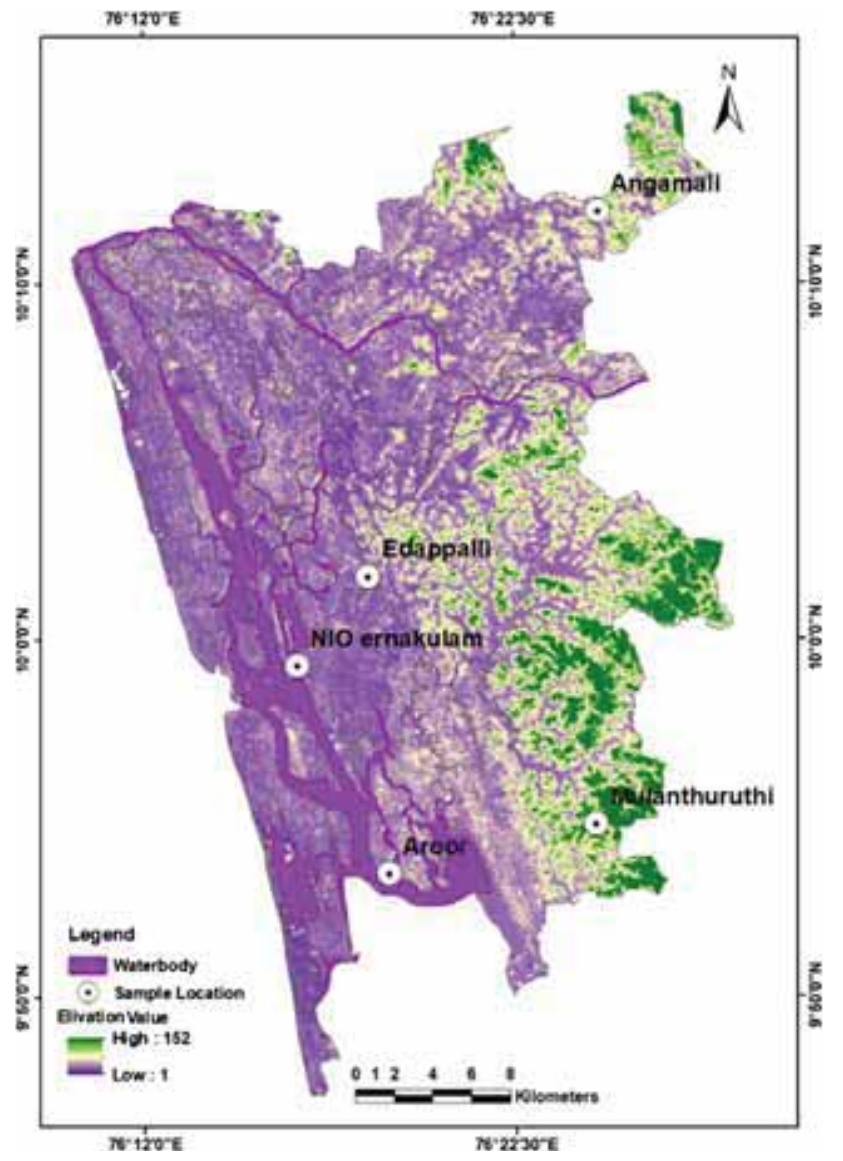

Figure 2. DEM of the study area with sample locations.

absorption spectrometer (Los Gatos Research (LGR) Triple Isotope Water Analyser (TIWA-45EP)). The accuracy and precision of the measurement for $\delta \mathrm{D}$ and $\delta^{18} \mathrm{O}$ were $\pm 0.2 \%$ and $\pm 0.06 \%$ at 3 sigma, respectively. Stable isotope compositions of hydrogen and oxygen in the samples are expressed using the conventional delta notation relative to the VSMOW in part per thousand. The representation is as follows:

$$
\delta(\%)=\frac{\left(R_{\text {sample }}-R_{\text {standard }}\right)}{R_{\text {standard }}} \times 1000,
$$

where $R$ represents either ${ }^{18} \mathrm{O} /{ }^{16} \mathrm{O}$ or the $\mathrm{D} / \mathrm{H}$ ratio.

To validate the results, back-trajectory analysis has been performed using Trajstat (GIS-based software) using a re-analysis model input from the Global Reanalysis data set (Draxler and Rolph 2003; National Oceanic and Atmospheric Administration 2017). The back-trajectory analysis was performed for $96 \mathrm{~h}$ at an altitude of $1500 \mathrm{~m}$ above the surface.

\section{Results and discussion}

The $\delta^{18} \mathrm{O}$ in rainwater varies from $-8.73 \%$ to $0.29 \%$ in urban, $-12.21 \%$ o to $2.59 \%$ in midland and $-9.99 \%$ to $0.97 \%$ in the lowland region. Similarly, $\delta \mathrm{D}$ values vary from $-62.15 \%$ o to $9.91 \%$, $-89.9 \%$ to $24.12 \%$ and $-71.31 \%$ to $14.05 \%$, respectively, as above. The standard deviation of isotope data shows a higher value for the midland region (Angamali and Mulanthuruthi), followed by lower values for the coastal and urban regions (table 1 ). The mean $\delta \mathrm{D}$ and $\delta^{18} \mathrm{O}$ values show a considerable decreasing pattern for midland, coastal and urban regions, respectively, suggesting altitude effect on these parameters. The reported lapse rate for $\delta^{18} \mathrm{O}$ and $\delta \mathrm{D}$ is $0.1 \%$ and $0.8 \%$ per $100 \mathrm{~m}$, respectively (Deshpande et al. 2003). But temporally, the altitudinal effect remains the same suggesting temperature-induced rainout process for controlling isotopic variation. However, significant variation in $\delta^{18} \mathrm{O}$ with rainfall (amount effect) was identified (figure $3 \mathrm{a}$ and $\mathrm{b}$ ). The weak correlation between the rainfall amount and its $\delta^{18} \mathrm{O} / \delta \mathrm{D}$ concentration suggest the reception of continuous moisture mass supply for the SWM current from the marine region before reaching the Cochin region (Unnikrishnan Warrier et al. 2015). Although the amount effect is not that significant during precipitation, seasonal and spatial variations in isotopic value are observed, emphasising different moisture source regions (figure $4 \mathrm{a}$ and b), these variations in isotopic composition was reported earlier by Resmi et al. (2016). A significant spatio-temporal variation in SWI composition is observed in the two-factor analysis of variance (ANOVA) without replication (table 2). ANOVA is performed for $\delta \mathrm{D}, \delta^{18} \mathrm{O}$ and $d$-excess on a spatiotemporal basis. From ANOVA analysis, $P$-value is found to be less than 0.05 , indicating a statistically significant difference in the mean values among different levels of location with respect to period. A significant level value for $P$, i.e., $P=0.153,0.133$ and 0.222 was observed for $\delta \mathrm{D}, \delta^{18} \mathrm{O}$ and $d$-excess, respectively. Although mean isotopic composition varies at various sampling points, maximum depleted and enriched isotopic values were observed on 15 November and 16 July, respectively (figures 5 and 6). This emphasises the assumption that rainfall received along the whole region was not derived from a single vapour mass body, the SWI data clearly indicate the enrichment and depletion contributed by the change in the moisture source, i.e., $\mathrm{BoB}$ and $\mathrm{AS}$, respectively. A 


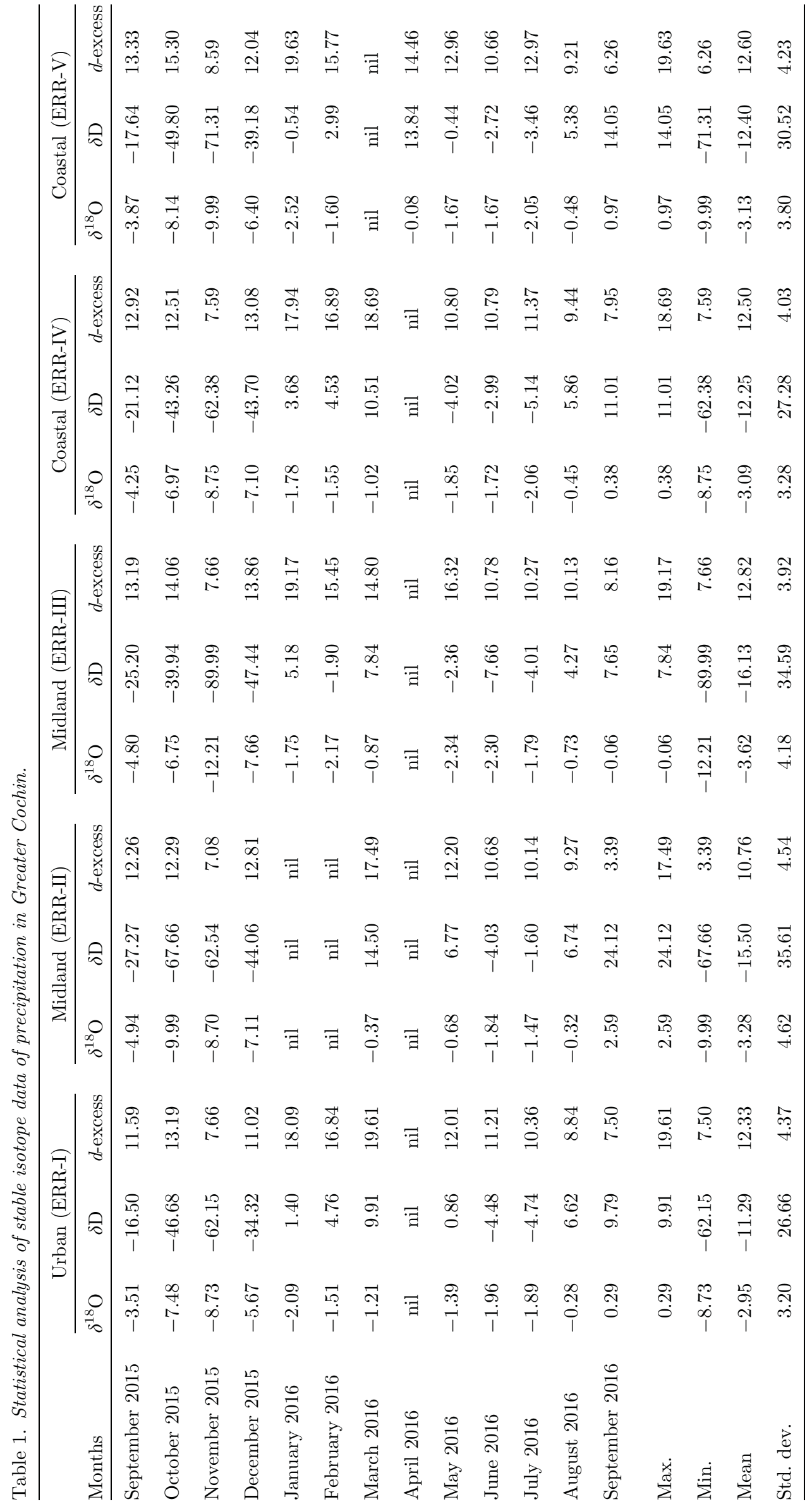



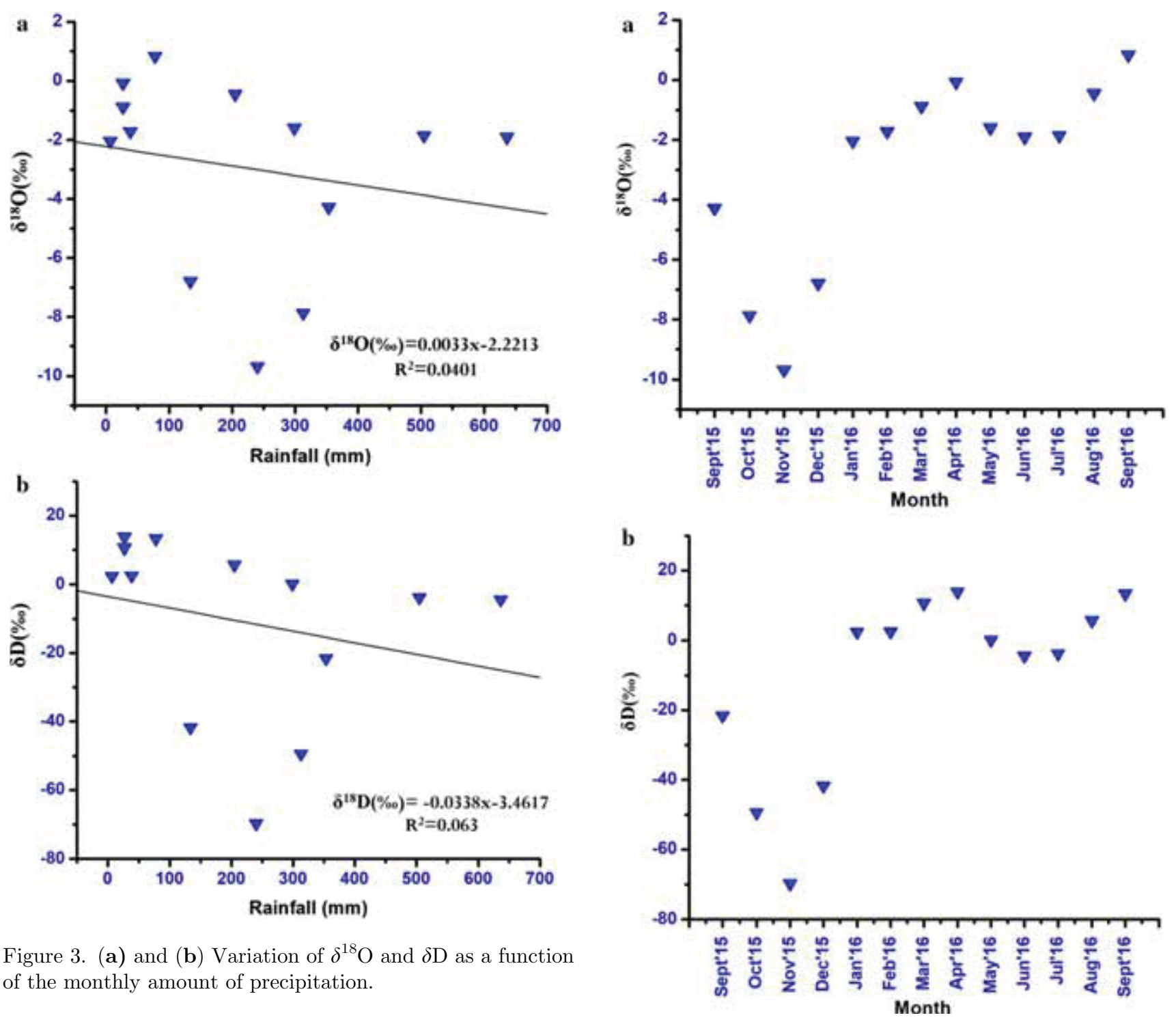

Figure 3. (a) and (b) Variation of $\delta^{18} \mathrm{O}$ and $\delta \mathrm{D}$ as a function of the monthly amount of precipitation.

depletion in isotopic signature in all study sites is observed during the month of October-December 2015 (NEM) followed by a gradual enrichment from January to September 2016. The depletion in isotopic composition during NEM may be due to the long distance transport of air moisture, causing depletion in SWI over Kerala, and this could be induced by the SWI depletion en-route termed as the continental effect. In addition to this, seasonal supply of freshwater from the Ganga and Brahmaputra river system may result in relatively lower $\delta^{18} \mathrm{O}$ in moisture generated during NEM (Lekshmy et al. 2014).

Temperature is a major factor controlling the variation of $\delta \mathrm{D}$ and $\delta^{18} \mathrm{O}$ in precipitation. The term temperature effect denotes the correlation of $\delta$-values with temperature (Schotterer et al. 1997). Pearson correlation analysis between stable isotope values and temperature is not showing a significant

Figure 4. (a) and (b) Monthly variations in $\delta^{18} \mathrm{O}$ and $\delta \mathrm{D}$ of precipitation in Greater Cochin.

relation with $\delta \mathrm{D}$ and $\delta^{18} \mathrm{O}(0.46$ and 0.136$)$. High temperature and low humidity can produce vapour mass with high $d$-excess (Unnikrishnan Warrior et al. 2010). In the present study, $d$-excess values are positively correlated with temperature, along with variation in humidity (supplementary figure S1) until the SWM period. Higher $d$-excess values were found during pre-monsoon ranging from $14.46 \%$ to $18.71 \%$ and the lowest values from $6.65 \%$ to $10.83 \%$ in SWM, and the variability can be attributed to the change in temperature and the oceanic moisture source associated with the SWM. Similar variability during SWM in the northeastern region was observed by Purushothaman et al. (2012). During SWM, the change in wind pattern occurring over the Indo-Gangetic plains 
Table 2. Analysis of variance (two-factor ANOVA) of isotope data of precipitation.

\begin{tabular}{lrrrrr}
\hline Source of variation & DF & \multicolumn{1}{c}{ SS } & \multicolumn{1}{c}{ MS } & \multicolumn{1}{c}{$P$} \\
\hline$\delta^{18} \mathrm{O}$ & & & & & \\
Location & 2 & 0.834 & 0.417 & 2.034 & 0.153 \\
Month & 12 & 361.636 & 30.136 & 146.965 & $<0.001$ \\
Residual & 24 & 4.921 & 0.205 & & \\
Total & 38 & 367.392 & 9.668 & & \\
$\delta \mathrm{D}$ & & & & & \\
Location & 2 & 70.25 & 35.125 & 2.196 & 0.133 \\
Month & 12 & $23,531.421$ & 1960.952 & 122.621 & $<0.001$ \\
Residual & 24 & 383.806 & 15.992 & & \\
Total & 38 & $23,985.477$ & 631.197 & & \\
$d$-excess & & & & & \\
Location & 2 & 18.857 & 9.429 & 1.601 & \\
Month & 12 & 629.001 & 52.417 & 8.903 & $<0.001$ \\
Residual & 24 & 141.302 & 5.888 & & \\
Total & 38 & 789.161 & 20.767 & & \\
\hline DF idegree & & & & \\
\hline
\end{tabular}

DF: degree of freedom; SS: sum of squares; MS: mean square; $F=$ F-ratio test.

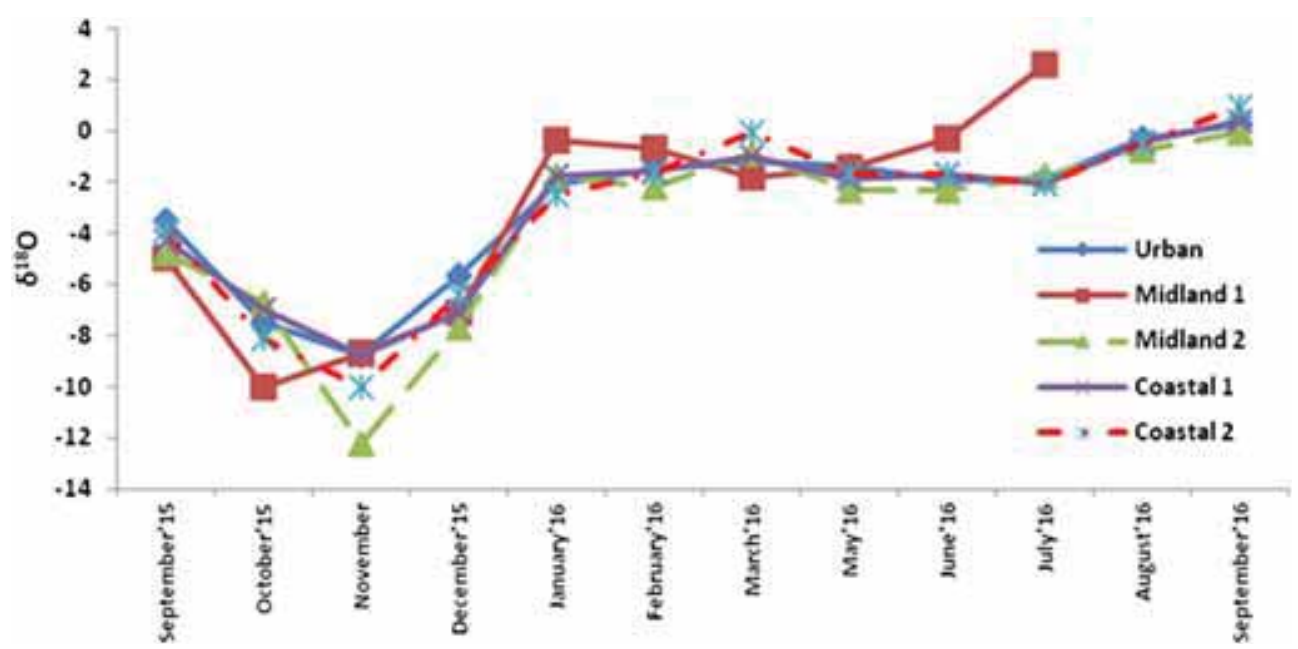

Figure 5. Spatial and temporal variation of $\delta^{18} \mathrm{O}$ of precipitation in the study area.

brings about the change in the weather condition. The moist air from AS during SWM travels across the continental region and picks up the moisture from the depleted BoB, leading to isotopic depletion in rainfall over northern India. The depletion of isotopic composition was observed 3-16 days prior to the first monsoon rainfall, which remains for 4-30 days even after the withdrawal of the monsoon season (Krishan et al. 2015).

The regression lines of $\delta^{18} \mathrm{O} v s . \delta \mathrm{D}$, i.e., LMWL for individual regions and precipitation samples from the entire study area are plotted above the GMWL (table 3 and figure 7). which indicates the reevaporated moisture from the vicinity of continental water bodies (Salati et al. 1979; Sonntag et al. 1983;
Ingraham and Taylor 1986). The slope and intercept values of the study area are $8.1( \pm 0.24)+12.8$ $( \pm 1.06)$ for coastal, $7.9( \pm 0.21)+11.9( \pm 1.09)$ for midland and $8.3( \pm 0.43)+13.1( \pm 1.73)$ for urban regions (figure 8). The overall LMWL for the study area is $\delta \mathrm{D}=8.06( \pm 0.15) \delta^{18} \mathrm{O}+12.5( \pm 0.68)$. On comparing the LMWL from the present study with that established by previous researchers, it was found that there is a slight variation in the slope value of the LMWL (a difference of 1.46 in slope value from Resmi et al. 2016). This variation can be due to the differences in the sampling periods, locations and corresponding meteorological events. Additionally, Resmi et al. (2016) considered a long stretch of sampling area to address the orographic 


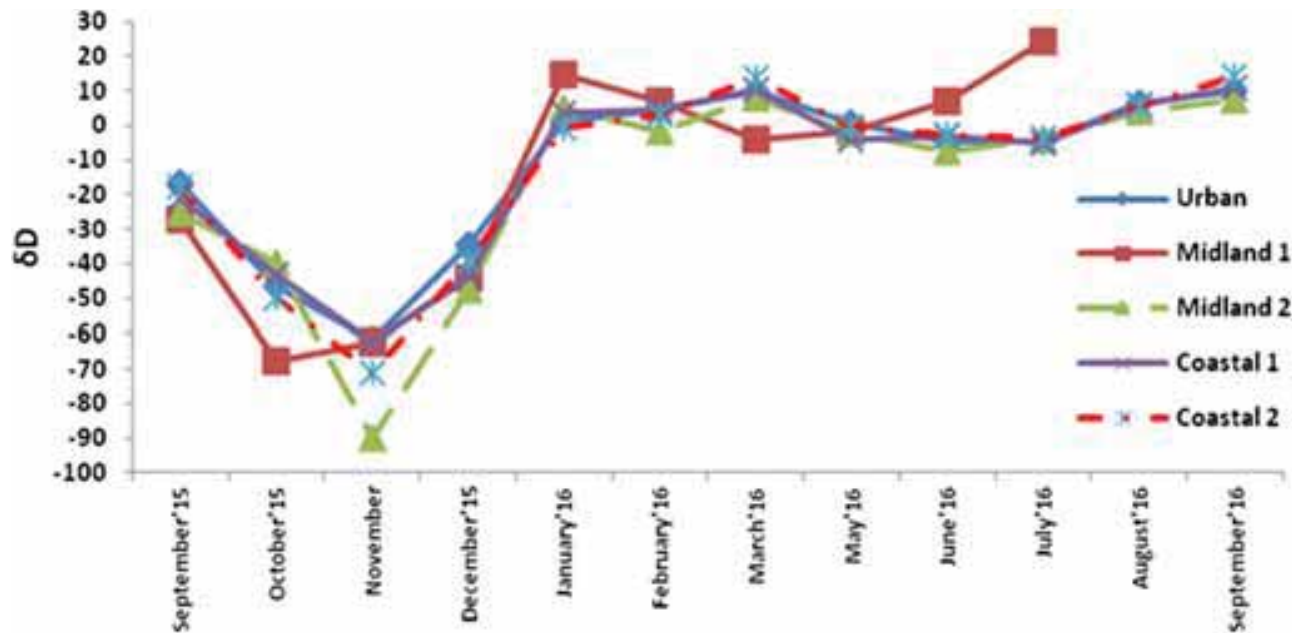

Figure 6. Spatial and temporal variation of $\delta \mathrm{D}$ of precipitation in the study area.

Table 3. Regression parameters of precipitation in different regions of Greater Cochin.

\begin{tabular}{lccc}
\hline Region & Slope $(\mathrm{m})$ & $Y$-intercept & $R^{2}$ \\
\hline Coastal & $8.1 \pm 0.24$ & $12.8 \pm 1.06$ & 0.9802 \\
Midland & $7.9 \pm 0.21$ & $11.9 \pm 1.09$ & 0.9854 \\
Urban & $8.3 \pm 0.43$ & $13.1 \pm 1.73$ & 0.9735 \\
All rains & $8.06 \pm 0.15$ & $12.5 \pm 0.68$ & 0.9815 \\
\hline
\end{tabular}

influence. While comparing the LMWL obtained from the present study with that established by Unnikrishnan Warrior et al. (2010), for the adjacent coastal area of Kozhikode, show a marginal variation in intercept values. LMWL of the present study was established from the analysis of samples collected for a period of 1 year, while previous researchers established LMWL from the sampling of meteoric water for more than 2 years. However, a uniform trend is observed during the SWM and NEM period indicating the constant nature of vapour sources.

The highest slope and intercept values are noticed in urban areas followed by the coastal region. The urban station is lying in the lowland and surrounded by large surface water bodies with an elevation of $\sim 5-10 \mathrm{~m}$ and is influenced by the coastal air blowing system. The densely populated tier II metropolitan area within the study area exhibits high surface temperature which will directly affect the spatial air temperature. Several recent studies (Oke 1981; Spronken-Smith and Oke 1998; Upmanis et al. 1998; Svensson et al. 2002) suggest an intra-urban air temperature difference of up to $9^{\circ} \mathrm{C}$, though urban heat intensities report magnitude up to $12^{\circ} \mathrm{C}$. The indirect influence of air temperature difference affects the air quality, stability and development of local wind systems (Eliasson and Holmer 1990; Kuttler and Romberg 1992; Eliasson and Upmanis 2000). As a result, evaporated/recycled vapour from these areas appear to be significant to the ambient vapour, considerably modifying the stable isotope compositions of water droplets falling through such saturated or dry air over the studied urban area. Additionally, the isotopic effects of precipitation over urban regions at different latitudes also need to be constrained in detail.

The deuterium excess ranges from $3.4 \%$ to $19.6 \%$ with a mean of $12.3 \%$ (figure 9 ). Since the study area is covered by plantation crops in the Midland region and surface water bodies in the urban and coastal regions, evapo-transpiration and evaporation may also have contributed towards the ambient vapour during the premonsoon season, increasing the $d$-excess values. During the SWM period, mean $d$-excess values are less $(10.1 \%$ o) than in the NEM (12.8\%o). The study brings about the regional experiences of two monsoons. The negative $d$-excess anomaly during JJAS suggests that the humidity of the Indian Ocean surface is relatively higher than the average relative humidity (Chakraborty et al. 2016). The post-monsoon or NEM carries vapour from the northern plain of India, which has a significant amount of continental vapour; the $d$-excess of the precipitation formed from this air mass is too large. The $d$-excess anomaly shows positive anomaly during the winter/spring period while monsoon months show a typically negative anomaly. One important aspect is that positive $d$ - 


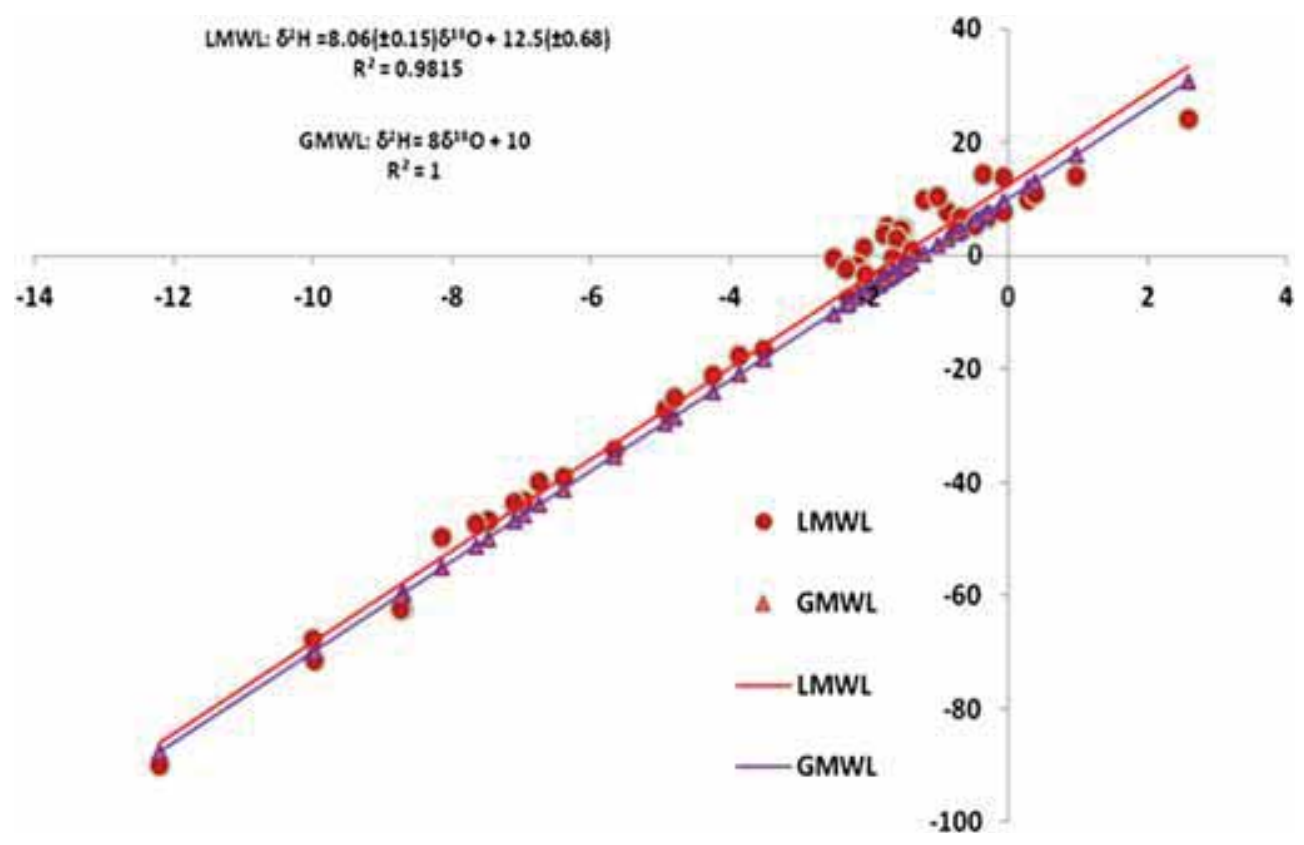

Figure 7. LMWL of the study area.

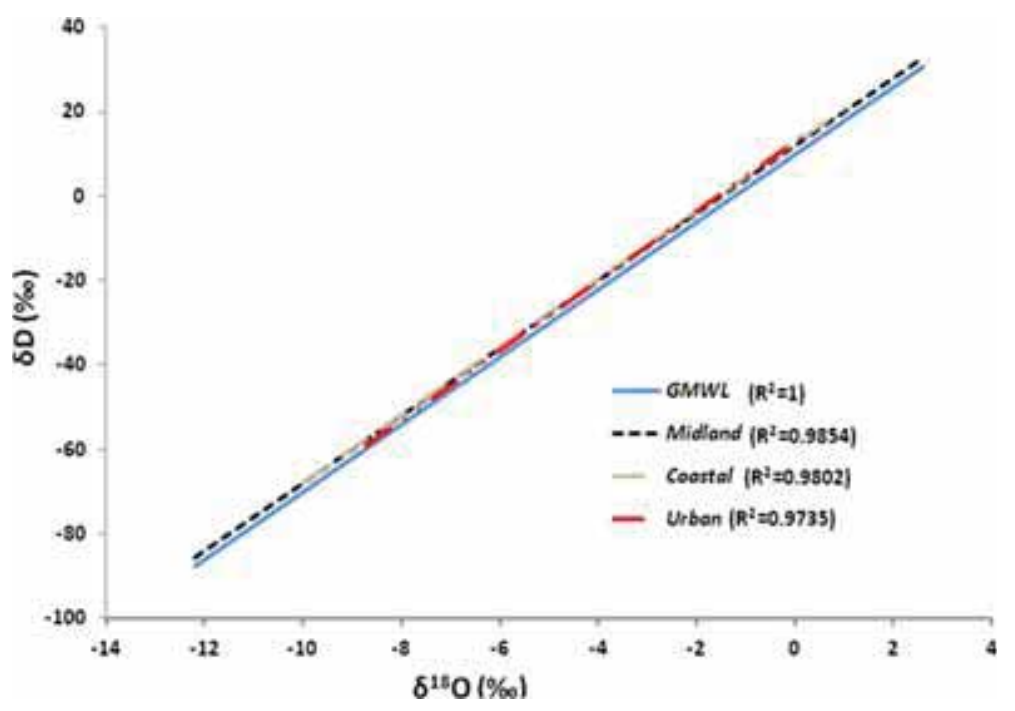

Figure 8. Regression plot of $\delta^{18} \mathrm{O}$ vs. $\delta \mathrm{D}$ of precipitation in different regions of Greater Cochin.

excess anomalies are usually associated with largescale organised convection during the summer monsoon season. Comparatively, the enriched isotope values and reduced $d$-excess values during February to April (pre-monsoon) indicate significant secondary evaporation during low-intensity rainfall. In the pre-monsoon period, the month of May receives relatively higher rainfall which leads to a sudden enrichment in the $d$-excess value, indicating the possibility of a marine moisture source from AS (Unnikrishnan Warrier et al. 2015). A sudden dip in the $d$-excess value was observed during 2015 November, which can be attributed to the deep depression formed in the BoB (supplementary figure S2). This has travelled to the west coast region resulting in the depletion of $\delta^{18} \mathrm{O}$. These findings are validated by backtrajectory analysis during the study period. Backtrajectory analysis suggests that the major source of precipitation during June-September (monsoon) is from the Indian Ocean, resulting in an enriched isotopic value. The lower $d$-excess from October to December indicates the dominant moisture source from the BoB and the continental region with depleted isotopic and higher $d$-excess value (figure 10). 


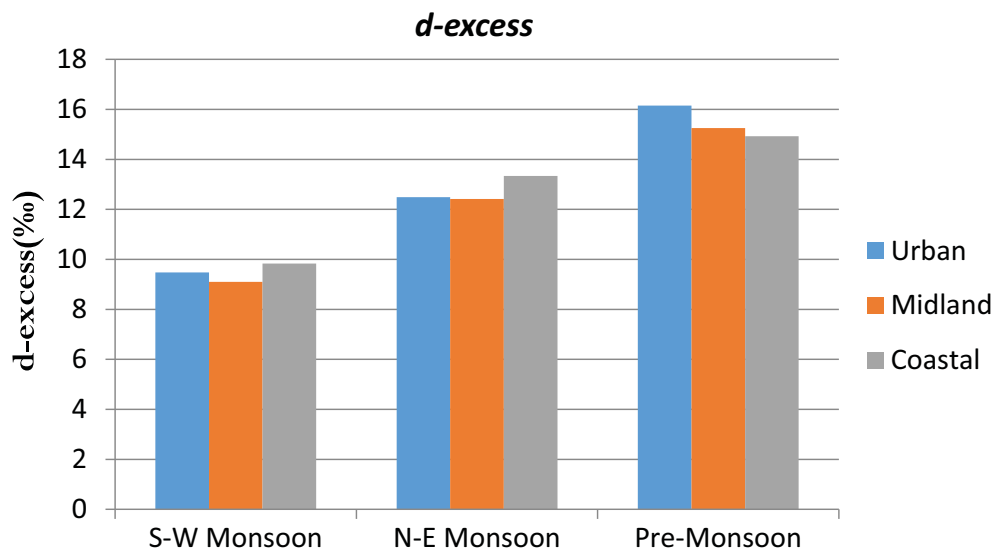

Figure 9. Seasonal variation of $d$-excess in the study area.

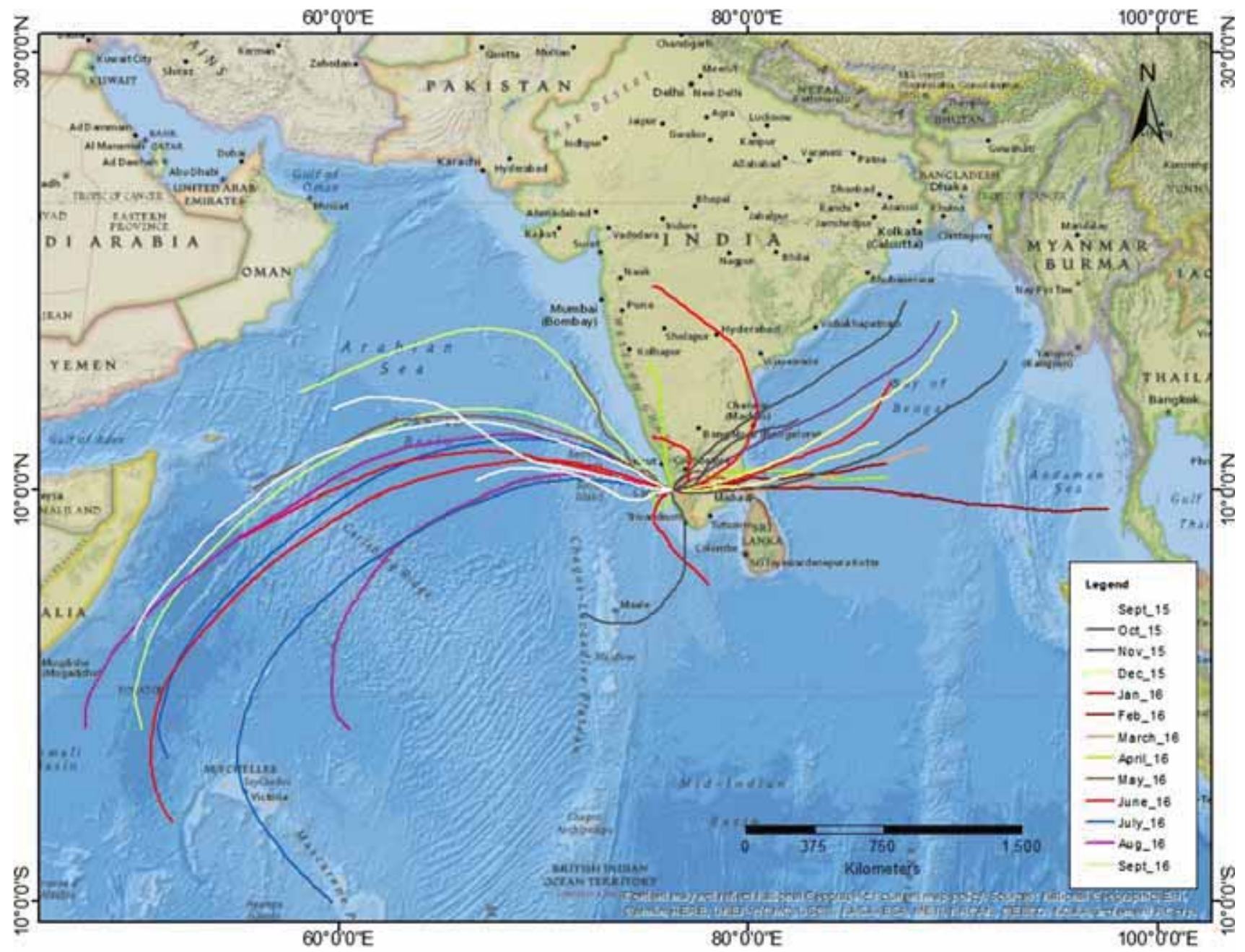

Figure 10. Back-trajectory analysis of the study area.

\section{Conclusion}

The stable isotopes of hydrogen and oxygen in precipitation of Greater Cochin, Kerala are investigated to analyse their spatio-temporal variations, sources of water vapour and generation of LMWL. The overall
LMWL for the study area is $\delta \mathrm{D}=8.06( \pm 0.15)$ $\delta^{18} \mathrm{O}+12.5( \pm 0.68)$. This study also envisages slope and intercept values from different locations as 8.1 $( \pm 0.24)+12.8 \quad( \pm 1.06) \quad$ for coastal, 7.9 $( \pm 0.21)+11.9( \pm 1.09)$ for midland and 8.3 $( \pm 0.43)+13( \pm 1.73)$ for urban regions. The $d$-excess 
and back-trajectory observations suggest that the study area receives SW and NE monsoon showing two distinct isotopic signatures resulting from the difference in rainout histories of the air masses and differences in vapour source. The composite precipitation samples collected from urban, coastal and midland regions showed spatial and temporal variations, even though meteorological parameters are more or less similar. The deuterium excess values and back-trajectory analysis also indicate vapour source from marine moisture during SWM and continental vapour for the NEM. The present study has significant implications in understanding the SWI composition and precipitation dynamics of the Indian monsoon in Greater Cochin region.

\section{Acknowledgements}

This work is funded by the Ministry of Earth Sciences (MoES), Government of India through the National Centre for Earth Science Studies (NCESS), Kerala. The authors are thankful to the Director of National Centre for Earth Science Studies (NCEES) and Director of National Centre for Antarctic and Ocean Research (NCAOR). The authors also acknowledge Dr Thamban Meloth for his valuable suggestions and for allowing us to avail the laboratory facilities at NCAOR.

\section{References}

Aneesh T D, Srinivas R, Nair A M, Prasad K R, Arun T J and Ande B 2018 Estimation of runoff with respect to temporal and spatial land use changes in Cochin Urban Agglomerate, India: A case-study of 2018 flood; Int. J. Sci. Eng. Res. 9(11) 498-502, https://doi.org/10.14299/ijser20181010.

Central Ground Water Board (CGWB) (1995-2004) Annual report and other related reports Central Ground Water Board, New Delhi.

Chakraborty S, Sinha N, Chattopadhyay R, Sengupta S, Mohan, P M and Datye A 2016 Atmospheric controls on the precipitation isotopes over the Andaman Islands, Bay of Bengal; Sci. Rep. 6 19555, https://doi.org/10.1038/srep19555.

Clark I D and Fritz P 1997 Environmental isotopes in hydrogeology; Lewis Publishers, Boca Raton, pp. 40-108.

Craig H 1961 Isotope variations in meteoric waters; Science 133(3465) 1702-1703.

Dansgaard W 1964 Stable isotopes in precipitation; Tellus 16(4) 436-468, https://doi.org/10.3402/tellusav16i48993.

Deshpande R D, Bhattacharya S K, Jani R A and Gupta S K 2003 Distribution of oxygen and hydrogen isotopes in shallow groundwaters from Southern India: Influence of a dual monsoon system; J. Hydrol. 271(1-4) 226-239.

Deshpande R D, Maurya A S, Kumar B, Sarkar A and Gupta S K 2010 Rain-vapor interaction and vapor source identification using stable isotopes from semiarid western India; J. Geophys. Res. 115 D23311.

Draxler R R and Rolph G D 2003 HYSPLIT (HYbrid SingleParticle Lagrangian Integrated Trajectory) model access via NOAA ARLREADY website (http://www.arlnoaagov/ ready/hysplit4html), NOAA Air Resources Laboratory, Silver Spring.

Eliasson I and Holmer B 1990 Urban heat island circulation in Göteborg, Sweden; Theor. Appl. Climatol. 42 187-196.

Eliasson I and Upmanis H 2000 Nocturnal airflow from urban parks - Implications for city ventilation; Theor. Appl. Climatol. 66 95-107.

Gammons C H, Poulson S R, Pellicori D A, Reed P J, Roesler A J and Petrescu E M 2006 The hydrogen and oxygen isotopic composition of precipitation, evaporated mine water, and river water in Montana, USA; J. Hydrol. 328(1-2) 319-330.

Gedzelman S, Lawrence J, Gamache J, Black M, Hindman E, Black R, Dunion J, Willoughby H and Zhang X 2003 Probing hurricanes with stable isotopes of rain and water vapor; Mon. Weather Rev. 131 1112-1127, https://doi.org/ 10.1175/1520-0493(2003)131\%3c1112:PHWSIO\%3e20CO;2.

Ghosh S K, Pant M C and Dewan B N 1978 Influence of the Arabian Sea on the Indian summer monsoon; Tellus $\mathbf{3 0}(\mathbf{2})$ $117-125$.

Good S P, Mallia D V, Lin J C and Bowen G J 2014 Stable isotope analysis of precipitation samples obtained via crowd sourcing reveals the spatiotemporal evolution of super storm sandy; PLoS One $\mathbf{9}(\mathbf{3})$ 1-7, https://doi.org/10. 1371/journalpone0091117.

Gonfiantini R 1986 Environmental isotopes in lake studies; In: Handbook of environmental isotope geochemistry (eds) Fritz $\mathrm{P}$ and Fontes J C, Elsevier, New York, Vol. 2, 113-168.

Gupta S K and Deshpande R D 2003 Synoptic hydrology of India from the data of isotopes in precipitation; Curr. Sci. 85(11) 1591-1595.

Gupta S K and Deshpande R D 2005 Groundwater isotopic investigations in India: What has been learned? Curr. Sci. 89(5) 825-835.

Hoffmann G, Cuntz M, Jouzel J and Werner M 2005 How much climate information bear the water isotopes? A systematic comparison between the IAEA/GNIP isotope network and the ECHAM4 Atmospheric General Circulation Model, pp. 303-320.

Houghton J T, Ding Y, Griggs D J, Noguer M and Linden P J V D 2001 Climate change 2001: The scientific basis; Cambridge University Press, Cambridge.

Hu C, Froehlich K, Zhou P, Lou Q, Zeng S and Zhou W 2013 Seasonal variation of oxygen-18 in precipitation and surface water of the Poyang Lake Basin, China; Isot. Environ. Health Stud. 49(2) 188-196.

Hunjak T, Lutz H O and Roller-Lutz Z 2013 Stable isotope composition of the meteoric precipitation in Croatia; Isot. Environ. Health Stud. 49(3) 336-345.

India Meteorological Department 2016 Meteorological Centre, Trivandrum, Kerala, http://www.imdtvmgovin.

Ingraham N L and Taylor B E 1986 Hydrogen isotope study of large-scale meteoric water transport in northern California \& Nevada; J. Hydrol. 85 183-197.

Kuttler W and Romberg E 1992 The occurrence and effectiveness of country breeze by means of wind tunnel and in situmeasurements; In: Proceedings of the 9th World Clean Air Congress, Montreal, Quebec, Canada, August 30-September 4, IU-9A04, pp. 1-2. 
Laskar A H, Sharma N, Ramesh R, Jani R A and Yadava M G 2010 Paleoclimate and paleo vegetation of lower Narmada Basin, Gujarat, Western India, inferred from stable carbon and oxygen isotopes; Quat. Int. 227 183-189, https://doi. org/10.1016/jquaint201005020.

Lekshmy P R, Midhun M, Ramesh R and Jani R A $2014{ }^{18} \mathrm{O}$ depletion in monsoon rain relates to large scale organized convection rather than the amount of rainfall; Sci. Rep. 45661.

Lekshmy P R, Midhun M and Ramesh R 2015 Spatial variation of amount effect over peninsular India and Sri Lanka: Role of seasonality; Geophys. Res. Lett. 42(13) 5500-5507, https://doi.org/10.1002/2015GL064517.

Mathieu R and Bariac T 1996 An isotopic study on water movements in clayey soils under semiarid climate; Water Resour. Res. 32 779-789.

Menon P A and Rajan C K 1989 Climate of Kerala, Cochin; Classic Publishing House, Cochin.

National Oceanic and Atmospheric Administration 2017 State of the climate in 2016, Special Supplement to the Bulletin of the American Meteorological Society, Vol. 98(8).

Oke T R 1981 Canyon geometry and the nocturnal urban heat island: Comparison of scale model and field observations; Climatology 1 237-254.

Oltmans S J and Hoffmann D J 1995 Increase in lowerstratospheric water vapor at a mid latitude Northern Hemisphere site from 1981 to 1994; Nature 374 146-149.

Purushothaman P, Rao M S, Kumar B, Rawat Y S, Krishan G and Devi P 2012 Comparison of two methods for ground level vapor sampling and influence of meteorological parameters on its stable isotopic composition at Roorkee, India; Hydrol. Processes 28(3) 882-894, https://doi.org/10.1002/hyp9623.

Rahul P, Ghosh P, Bhattacharya S K and Yoshimura K 2016 Controlling factors of rainwater and water vapor isotopes at Bangalore, India: Constraints from observations in 2013 Indian monsoon; J. Geophys. Res. Atmos. 121 13,936-13,952. https:// doi.org/10.1002/2016JD025352.

Resmi T R, Sudharma K V and Hameed A S 2016 Stable isotope characteristics of precipitation of Pamba River basin, Kerala, India; J. Earth Syst. Sci. 125(7) 1481-1493.

Rhodes A L, Guswa A J and Newell S E 2006 Seasonal variation in the stable isotopic composition of precipitation in the tropical mountain forests of Monteverde, Costa Rica; Water Resour. Res. 42 W11402, https://doi.org/10.1029/2005WR004535.

Roderick M L and Farquhar G D 2002 The cause of decreased pan evaporation over the past 50 yrs; Science 298 1410-1411, https://doi.org/10.1126/science1075390.

Rozanski K, Sonntag G and Munnich K O 1982 Factors controlling stable isotope composition of European precipitation; Tellus 34 142-150.

Rozanski K, Araguás-Araguás L and Gonfiantini R 1993 Isotopic patterns in modern global precipitation; In: Climate change in continental isotopic records (eds) Swart P K, Lohmann K L, McKenzie J and Savin S, American Geophysical Union, Washington DC, pp. 1-37.

Salati E, Dall'Olio A, Matsui E and Gat J R 1979 Recycling of water in the Amazon Basin: An isotopic study; Water Resour. Res. 15 1250-1258.

Sanyal P and Sinha R 2010 Evolution of the Indian summer monsoon: Synthesis of continental records; J. Geol. Soc. London, Spec. Publ. 342(1) 153-183.
Saranya P, Krishan G, Rao M S, Kumar S and Kumar B 2018 Controls on water vapor isotopes over Roorkee, India: Impact of convective activities and depression systems; $J$. Hydrol. 557 679-687.

Schotterer U, Frohlich K and Gaggeler H W 1997 Isotope records from Mongolian and Alpine ice cores as climate indicators; Clim. Change. 36 519-530.

Simpkins W W 1995 Isotopic composition of precipitation in central Iowa; J. Hydrol. 172(1-4) 185-207.

Soman M K, Krishna K K and Singh N 1988 Decreasing trend in the rainfall of Kerala; Curr. Sci. 57 7-12.

Sonntag C, Rozanski K, Miinnich K O and Jacob H 1983 Variations of deuterium \& oxygen-18 in continental precipitation \& groundwater \& their causes; In: Variations in the Global Water Budget (eds) StreetPerrott A et al., D. Reidel Publishing Company, pp. 107-124.

Spronken-Smith R A and Oke T 1998 The thermal regime of urban parks in two cities with different summer climates; Int. J. Remote Sens. 19(11) 2085-2104.

Stumpp C, Klaus J and Stichler W 2014 Analysis of long-term stable isotopic composition in German precipitation; J. Hydrol. 517 351-361.

Svensson M, Eliasson I and Holmer B 2002 A GIS-based empirical model to simulate air temperature variations in the Göteborg urban area during the night; Clim. Res. 22(3) $215-226$.

Tremoy G, Vimeux F, Mayaki S, Souley I, Cattani O, Risi C, Favreau G and Oi M 2012 A 1-yr long $\mathrm{d}^{18} \mathrm{O}$ record of water vapor in Niamey (Niger) reveals insightful atmospheric processes at different timescales; Geophys. Res. Lett. 39 1-5, https://doi.org/10.1029/2012GL 051298.

Trenberth K E 2002 Changes in tropical clouds and radiation; Science 296 2095, https://doi.org/10.1126/science2 9655762095a.

Unnikrishnan Warrier C and Babu M P 2011 A comparative study on isotopic composition of precipitation in wet tropic and semi-arid stations across southern India; J. Earth Syst. Sci. 120(6) 1085-1094.

Unnikrishnan Warrier C, Praveen Babu M, Manjula P, Velayudhan K T, Shahul Hameed A and Vasu K 2010 Isotopic characterization of dual monsoon precipitation Evidence from Kerala, India; Curr. Sci. 98(11) 1487-1495.

Unnikrishnan Warrier C, Praveen Babu M, Sudheesh M and Deshpande R D 2015 Studies on stable isotopic composition of daily rainfall from Kozhikode, Kerala, India; Isot. Environ. Health Stud. 52(3) 219-230, https://doi.org/10. 1080/1025601620161103238.

Upmanis H, Eliasson I and Lindqvist S 1998 The influence of green areas on nocturnal temperatures in a high latitude city (Göteborg, Sweden); Int. J. Climatol. 18 681-691.

Wassenaar L I, Athanasopoulos P and Hendry M J 2011 Isotope hydrology of precipitation, surface and ground waters in the Okanagan Valley, British Columbia, Canada; J. Hydrol. 411(1-2) 37-48. 